\title{
Analysis of Farmer's Perception of Partnership Patterns in Bumi Dipasena Indonesia
}

\author{
M Yusuf S Barusman* \\ Faculty of Economics and Business, University of Bandar Lampung Jl. Zainal Abidin Pagar Alam No.26, \\ Labuhan Ratu, Kedaton, 35142, Bandar Lampung, Indonesia E-mail: yusuf.barusman@ubl.ac.id \\ Budhi Waskito \\ Faculty of Social and Political Science, University of Bandar Lampung Jl. Zainal Abidin Pagar Alam No.26, \\ Labuhan Ratu, Kedaton, 35142, Bandar Lampung, Indonesia
}

\begin{abstract}
The aim of this study is to find out perceptions of farmers regarding the partnership relationship that is carried out on the earth dipasena and whether the applicable partnership pattern is in accordance with the people's economic system. There are several types of economic systems that are carried out in Indonesia. Two of them are the populist economic system and the democratic Economic system. The populist economic system is based on people's independence or in other words, from the people, by the people, and for the people. While, the Democratic Economic System is an economic system that refers to the mandate of the national constitution, so that an idiomatic and constitutional foundation is a legal product that regulates (related to) the life of the national economy. This study uses a case study methodology. The result is not all dimensions of people's economy. The result is not all dimensions of people's economy have been reflected in the implementation of the shrimp farming business in Dipasena Jaya Village.
\end{abstract}

Keywords: Perception, Partnership Patterns, Economic system

DOI: $10.7176 / \mathrm{JESD} / 10-4-16$

\section{Introduction}

Bumi Dipasena is a village in the sub-district of Rawajitu Timur, Tulang Bawang Regency, Lampung, Indonesia. The area is formed into thousands of hectares of shrimp farm land completed with intensive supporting facilities for shrimp farming with village division. Not only are there a lot of pond plots, but there also stands power houses, cold storage, shrimp feed factories, workshops, export, medical ports, elite offices, and many more complete social and economic facilities with a total land area of 16,250 HA, divided into independent farms (ex plasma) types of SHM: 6,800 Ha (3,613 Ha cultivation area, 3,187 Ha supporting infrastructure area) and ex CPP Group (ex core) types of HGU area of 9,450 Ha. The total number of farms is 17.139 plots consisting of productive ponds of 14,609 plots and ponds that are less productive (utilized by residents of these ponds is a failure of the CPP group reservoir system). One of the villages built based on the manufacture of one of the largest shrimp farms in the world PT. Dipasena Citra Darmaja is Bumi Dipasena Utama. (Profile of Bumi Dipasena, 2016). At its inception, Bumi Dipasena Village was the village with the largest commodity of shrimp farms in the world. The glory of PT. Dipasena Citra Darmaja (PT DCD) did not last long. Around 1990-1999, the economic crisis that hit Indonesia caused PT DCD to experience problems. After PT DCD was declared bankrupt and liquidated by the government, the Dipasena shrimp ponds changed hands several times and experienced ups and downs. Until now, shrimp farms on Bumi Dipasena are managed by PT Setiga Sukses Bersama (PT SSB).

Bumi Dipasena has 8 villages in it, namely, Bumi Dipasena Sentosa, Utama, Agung, Jaya, Mulya, Makmur, Sejahtera, and Abadi. One of them, Bumi Dipasena Jaya village, together with its community, under the Association of Wind Shrimp Entrepreneurs Association (P3UW), is implementing a Business with Communities with a unique or different Partnership Pattern and Financial Pattern. Like the financial patterns applied, all communities are shareholders and farmers. With a profit sharing system, there is a risk sharing system, a distribution system for information and a system for distributing infrastructure. Each shareholder will provide a portion of his harvest for the sharing system. The following is the calculation of the results: 
Table 1. Pattern of Profit Sharing

\begin{tabular}{|c|c|c|c|}
\hline No & COMPONENT & CODE & DESCRIPTION \\
\hline 1 & SALES & A & $\begin{array}{c}\text { The results of the Cultivator's } \\
\text { business }\end{array}$ \\
\hline 2 & CULTIVATION COST & B & Collection of funds from investors \\
\hline 3 & GROSS RESULTS & C & A minus B \\
\hline 4 & INFAQ & D & $2,5 \%$ of C \\
\hline 5 & RESULTS AFTER INFAQ & E & C minus D \\
\hline 6 & RESERVES OF BUSINESS RISK & F & $10 \%$ of E \\
\hline 7 & RESULTS OF PARTIES & G & E minus F \\
\hline 8 & CULTIVATORS & H & $80 \%$ of G \\
\hline 9 & INVESTORS & I & $15 \%$ of G \\
\hline 10 & MANAGEMENT of BUMDes (village-owned business & J & $5 \%$ of G \\
\hline
\end{tabular}

With the profit sharing system it will affect the mindset and farmers. With the risk sharing, for example, the risk of failing to harvest one farm is borne jointly by all shareholders. They look after each other and help each other so that there are no common harmful problems. However, out of a total of 6,500 farmer family heads there, only 1000 people follow this partnership pattern while the other 5,000 are not willing to follow this partnership pattern.

We know that there is an economic system based on people's independence or in other words, from the people, by the people, and for the people. This is called the populist economic system. The Democratic Economic System is an economic system that refers to the mandate of the national constitution, so that an idiomatic and constitutional foundation is a legal product that regulates (related to) the life of the national economy. The Ideal Foundation of the Democratic Economic System is the values of Pancasila as the Indonesian nation's value system to realize the five principles in every economic activity.

What about the partnership pattern applied on Bumi Dipasena? What are the perceptions of farmers, on the existing partnership patterns and have the partnership patterns covered the dimensions of the people's economic system?

\section{Literature Review}

\subsection{Perception}

Kotler et al (2012) states that perception is where we choose, organize, and translate information input to create a meaningful picture of the world. This is a process of using something that is received through the five senses.

Perception can also be interpreted as all processes of selecting, organizing, and interpreting information input. It is the sensations received through vision, feeling, hearing, smell, and touch that produce meaning (Pride and Ferrel in Fadila and Lestari (2013). Besides that perception is a process of selecting, regulating, and interpreting information (Boyd, Walker, and Larreche in Fadila and Lestari (2013). Perception also shares a bonding relationship with behavior (Oyeyemi, 2015).

Gibson, et al (1950) stated that there are 2 factors that influence perception, namely:

1. Internal factors that affect perception.

Internal factors are the factors contained in the individual, including:

a. Physiological Information entered through the sensory devices. Furthermore, the information obtained will affect and complement the business to perceive each person differently so that the interpretation of the environment can also be different.

b. Attention from Individuals requires a certain amount of energy spent to pay attention to or focus on physical forms and mental facilities that exist in an object. The energy of each person varies so that one's attention to objects is also different and this will affect the perception of an object.

c. The interest in perception of an object varies depending on how much energy or perceptual vigilance is moved to perceive. Perceptual vigilance is a person's tendency to pay attention to a particular type of stimulus or can be said to be an interest.

d. Unidirectional Needs. This factor can be seen from how strong an individual is looking for objects or messages that can provide answers according to him.

e. Experience and Memory. Experience can be said to depend on memory in the sense of the extent to which a person can remember past events to know an excitement in a broad sense.

f. Mood. The state of emotion influences a person's behavior, this mood shows how someone feels at times that can influence how someone in accepting, reacting, and remembering.

2. External factors that influence perception are characteristics of the environment and objects seen in them. These factors can change a person's point of view of the world around him and influence how someone feels it or accepts it. 
External factors that influence perception include:

a. Size and Placement of Objects or Stimulus. This factor states that the greater the relationship of an object, the easier it is to understand. This form will affect individual perceptions and by looking at the shape of the size of an individual object it will be easy to pay attention in turn forming perceptions.

b. The color of objects. More objects that affect light are more easily understood (to be perceived) than few.

c. Uniqueness and Contrast of Stimulus. 15 external stimuli whose appearance with background and surroundings is totally beyond the expectations of other individuals will attract much attention.

d. Intensity and Strength of Stimulus. External stimuli will give more attention to meaning than those only seen once. The strength of a stimulus is the power of an object that can influence perception.

e. Motion or Movement. Individuals will pay much attention to objects that provide movement in the range of sight compared to objects that are stationary.

\subsection{Partnership Pattern}

Based on the laws of the Republic of Indonesia No. 9 of 1995, partnerships are business cooperation between small businesses and medium-sized businesses or large businesses accompanied by guidance and development by medium-sized businesses or large businesses by taking into account the principle of mutual need, mutual reinforcement and mutual benefit.

The essence of the partnership is also called mutual cooperation or cooperation from various parties, both individually and in groups. According to Notoatmodjo (2003), partnerships are a formal collaboration between individuals, groups, or organizations to achieve a specific task or goal.

According to Utama (2009) there are several bases in building a partnership, namely:

1. Common interest or concerns,

2. Trust each other and respect each other

3. Clear and measurable goals

4. Willingness to sacrifice time and energy as well as other resources.

The partnership principles are:

1. Equations

2. Openness or transparency

3. Mutual benefit.

\subsection{Democratic Economic System}

Democratic economy, as stated in Article 33 of the 1945 Constitution 3, is an economic system aimed at realizing people's sovereignty in the economic field. The three basic principles of popular economy are as follows: (1) the economy is structured as a joint venture based on the principle of kinship; (2) production branches that are important to the state and which control the livelihood of many people are controlled by the state; and (3) the earth, water, and all the assets contained in it are controlled by the state and used for the greatest prosperity of the people.

According to Zulkarnain (2006) ${ }^{4}$, in his book entitled: Entrepreneurship (Strategy for Empowering Small and Medium Enterprises and Poor Population), popular economy is an economic system that must be adhered to in accordance with our country's philosophy which concerns two aspects, namely justice and economic democracy, and partiality to the people's economy.

Putra (2015) divides the dimensions of people's economy into three important points, namely, community empowerment, public policy (the participation of the government), and the development of the concept of entrepreneurship. Whereas according to Malau (2016) populist economy as a new paradigm and strategy in Indonesia's economic development consists of nineteen dimensions, including, based on people's economic strength, self-reliance in managing economic resources, SMEs, community empowerment, employment opportunities, decent livelihoods for the community, social security for the community, equitable capital ownership, education for the community, independence of the community to establish and become members of economic unions, the role of the government, equitable economy, participatory economy, economic sustainability, government planning, market mechanisms, cooperation, equitable control of factors production and partnership production relationship patterns.

Based on some of these definitions, the dimensions of people's economy can be categorized into four dimensions, namely, empowerment and independence of the community in controlling economic resources, ranging from capital, assets and production processes and product marketing (From the People, By the People, to the People), government participation in determining public policies that support, develop entrepreneurship so as to open business opportunities and employment opportunities and uphold the principle of cooperation that is family-based and moral in Pancasila.

There are several steps or efforts that must be considered in realizing or developing a populist economy so that these objectives are implemented properly, namely:

1. Identify economic actors, such as cooperatives, small businesses, farmers and farmer groups regarding their 
potential and business development.

2. Conduct a program of guidance for these actors through a companion program.

3. Training education programs according to their needs at the time of developing the business.

4. Coordinate and evaluate those involved in the development process, both guidance on capital, human resources, markets, market information, and the application of technology. (Zulkarnain,2006)

\section{Methodology}

This study uses a case study methodology. According to Yin in Corcoran et al. (2004) $)^{9}$, case studies allow a researcher to reveal the number of factors that have interacted to produce unique characters from the entity that is the subject of research. They represent methods of investigating complex examples through description and contextual analysis. The results are descriptive and theoretical in the sense that questions are asked about why they happened as they did and related to what might be important to explore in the same situation. A case study investigates contemporary phenomena in real life contexts when the boundaries between phenomena and contexts are unclear and where various sources of evidence are used.

Case studies have many differences, depending on the purpose of the study, the size of the study, the people involved, the theory developed, and the theory being tested. Bassey in Corcoran et al. (2004) ${ }^{11}$ define various objectives for educational case studies, which include search-theory research and case study testing, storytelling and drawing, and evaluative case studies. Case studies can involve descriptions, explanations, evaluations, and predictions. To do data analysis, data collection must be done first.

In this study, data was collected through literature studies, field observations, in-depth interviews, and focus group discussions (FGDs) with resource persons acting as representatives of the parties involved in Bumi Dipasena.

\section{Result and Discussion}

\subsection{History of Farmers}

Farmers on Bumi Dipasena began farming in 1990-1991. Initially the farmers were migrants who were looking for jobs in Dipasena; starting from the process of registering, participating in training, apprenticeship, and placement as a plasma farmer. The total number of villages on Bumi Dipasena has been affected starting from after the conflict until now, there are 8 villages. 8 villages joined in the Regional Shrimp Plasma Farmers Association (P3UW). Previously, farmers joined the company, but with a variety of losses that were felt, the farmers carried out guerrillas which began in 1997. The struggle has successfully been carried out until now.

In its implementation, one farmer manages 1 lot of ponds or 2 plots. The current status of farm ownership is owned by each farmer, in the form of a certificate of ownership. The size of the pond is $2000 \mathrm{~m}$, for 2 ponds (half a hectare). 1 lot or 2 ponds can produce up to 3 tons of shrimp.

\subsection{Process of Shrimp Cultivation and the role of stakeholders in it}

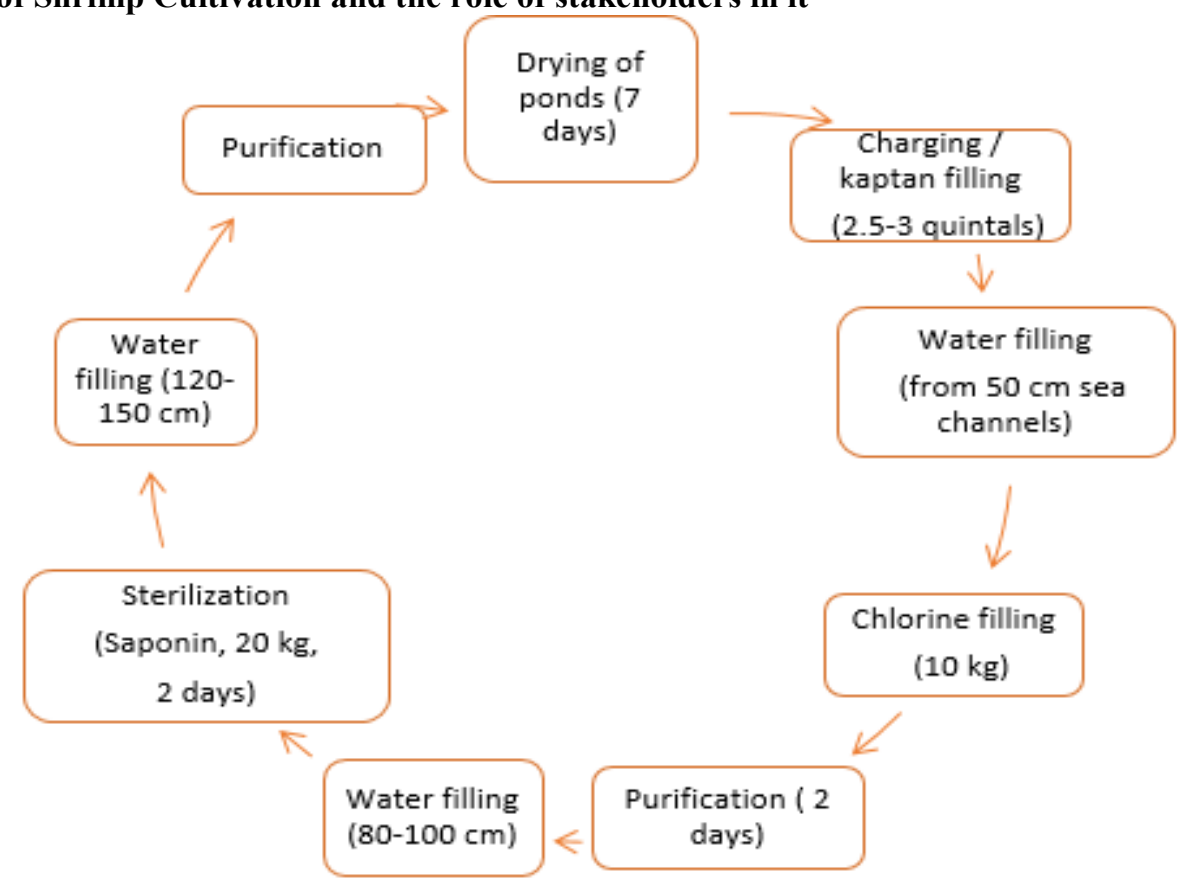

Figure 1.

Vaname Shrimp Cultivation Process in Bumi Dipasena 
The process of shrimp farming, based on the experience of farmers in one year, consists of 4 cycles of shrimp farming. Of the 4 cycles, only 1 cycle failed to harvest, usually months 7 and 8.3 other cycles are normal so farmers can harvest and the results depend on the climate. The problem that is felt by farmers is that during the bad season, there are farmers who can still harvest normally even a lot but there are those who get worse. In addition, the biggest problem faced by farmers is the problem of leaky ponds and electricity related to operational costs. Currently farm operations use a diesel engine, where one lot of farms use 20 liters of diesel per day for the operation of the mill then multiplied by usage for 70 days with full use of the windmill for 1.5 months.

The fries in Dipasena are sent from Kalianda with the age of 10-12 days and still in the form of larvae. The first time it is stocked, the farm has not been chained for 25 days - 1, after which it is carried out at midnight. Monitoring of enchantment is carried out by farmers. However, between farms usually supervise each other because there is a sense of belonging to one another. The difference is that if it was still managed by the company, now there are supervisors who oversee and technicians who make repairs. Farmers feel spoiled, but now the farmers are watching and helping each other.

For the procurement of fries and saprotam, coordination with the procurement of goods in cooperatives is carried out. But farmers are free to take fry and saprotam anywhere, if there is something cheaper than cooperatives, including selling crops as long as the highest price. The cooperative will only calculate the operational expenses during the SHU calculation if the farmer takes the fry and saprotam supplies from the cooperative.

The function of the cooperative itself is to gather information from internal and external. For example the determination of the amount of stocking and anticipation of climate is the task of the existing cultivation team in the cooperative by checking water conditions and anticipating the climate.

The process of selling shrimp harvest, namely, shrimp harvested is collected by the buyer and sent to collectors, and then sold to the factory. For example, if harvesting, the person in charge of harvesting in a business unit (UB) coordinates between business units and takes the highest price. Other buyers will follow the highest price. That way the most fortunate are farmers who join UB.

\subsection{Partnership Pattern and Perception of Farmers on the CRU Concept}

The partnership pattern that is implemented is that the farmer manages aquaculture activities, and the aquaculture activities are organized by a cooperative called BUSB (sub-block business entity). Capital or investment is joint capital. The business concept uses the concept of a CRU (Business Risk Reserve). The concept of a Business Risk Reserve (CRU) has been running for 3-5 years. But not all farmers use the CRU concept especially those who have not joined UB (joint venture). They are still being guided by buyers. In this case, farmers who have not joined UB are still given capital by buyers and share profits with buyers. The difference is, if farmers who have not joined UB suffer losses, they will become debt to the buyers. However, for farms incorporated in UB, they have been assisted with a CRU system (Business Risk Reserves). When a farmer gets a profit or surplus he will put his money into the CRU but when he loses he can still do shrimp farming by taking funds from the existing CRU. In essence, the risk is borne together.

Farmers who have not joined the CRU concept want to join UB but are still in debt. The reason for the farmers to follow the CRU concept is that their capital is joint capital, the work done together, they supervise each other, and mutual cooperation. While the reasons for farmers who have not joined the CRU concept are usually because they are still dependent on the buyer and bound by debt.

With the CRU concept (setting aside $10 \%$ of sales), farmers feel more positive in terms of management. For example, if there is a problem with crop failure, cross-subsidies can be made for the finances of ponds in a business unit, and when surplus, farmers can contribute to the CRU. The easy way is with the CRU concept, in 3 good cycles of shrimp farming, farmers can save for the preparation of 1 bad cycle.

In essence, the benefits of the CRU are to make farmers become indebted if they fail to harvest because they have saved at the beginning. This means harvest failure can be borne together. Then the concept of mutual cooperation and togetherness is built because the risks are shared. There is an Infaq concept $(2.5 \%)$, which is intended to repair roads, bridges, schools, help places of worship, and build other facilities.

In addition to the CRU concept, cooperatives or business units cooperate with farmers with funds of 1000 rupiah, i.e. in $1 \mathrm{~kg}$ of shrimp given 1000 rupiah to P3UW cash to buy heavy equipment (excavator). Excavators are used to improve facilities and infrastructure in the village. Then there is also what is called emergency debt. Farmers who experience financial difficulties will be assisted with emergency debt and will be returned at harvest and without interest.

Then there is the distribution of infaq percentage $(2.5 \%)$. The term infaq can be replaced with the name of assistance or donation because not all farmers are Muslims. Each UB has a different concept for its social information. The calculation is from $2.5 \%, 70 \%$ for development in each region, $20 \%$ for Muslims to the mosque, and $10 \%$ for donations that are sick. $10 \%$ can be donated between UB if anyone needs it. For non-Muslim farmers, the $2.5 \%$ infaq concept is donated according to the percentage to other churches or houses of worship. Management of this infaq works with the local hamlet head. 
In its organizational structure, P3UW acts as an umbrella or party that embraces the shrimp farm business. In other words, P3UW is the coordinator and liaison of overall communication and business control. In addition there is BPI (Infra Management Board) which is NGOs.

\subsection{Conformity with the Democratic Economy}

Based on some of these definitions, the dimensions of people's economy can be categorized into four dimensions, namely, empowerment and independence of the community in controlling economic resources, ranging from capital, assets and production processes and product marketing (From the People, By the People, to the People), government participation in determining public policies that support, develop entrepreneurship so as to open business opportunities and employment opportunities and uphold the principle of cooperation that is family-based and moral in Pancasila. Almost the four dimensions of the people's economy have been reflected in the implementation of the shrimp farming business in Dipasena Jaya Village.

4.3.1 Empowerment and independence of the community in mastering economic resources, starting from capital, assets and production processes and product marketing (From the people, by the people, to the people).

In this case, it can be seen from the process of shrimp farming where farmers are the core actors of all cultivation activities. Starting from the input process, namely buying and stocking seeds, farmers have the right to choose who they will buy seeds and how many seeds will be spread per farm. This also continues through coordination with the Business Unit (UB) that is in the Village Community Business Entity (BUMKAM). Furthermore, the process of shrimp farming requires saprotam and fuel oil. Farmers also have the right to choose the saprotam that will be used for their farms and who will buy the saprotam and fuel needed. Furthermore, in the process of selling shrimp yields, Farmers have the right to whom their crops will be sold with the principle agreed upon with UB and other farmers in UB, namely, the highest price, the fastest selling / paying, and the best service. In essence, all aspects of the shrimp farming process are optimized for the good of farmers.

4.3.2 Government participation in determining supporting public policies.

For government participation, in the business process of shrimp farming in Bumi Dipasena Village, what is seen is the role of the Village Government or in other words the village level. Actors involved in the Village Government are also actors who are actively involved in aquaculture activities on Bumi Dipasena. The function of the Village Government in this case is to oversee the cultivation activities and business of shrimp farms. In addition, the role or participation of the Government has not been seen. This can be seen from the condition of the infrastructure both roads and bridges that are not good and the inhabitants of Bumi Dipasena also strive to maintain and manage the existing infrastructure for the survival of the farmers.

4.3.3 Develop entrepreneurship so as to open business opportunities and job opportunities.

The concept of entrepreneurship run by Bumi Dipasena Village farmers currently focuses on shrimp farming entrepreneurship and other business opportunities from complementary shrimp farming products, ranging from seeds, saprotam, and fuel to windmills and also the opportunity to become shrimp collectors and distributors. In addition to shrimp farming and the sale of harvest products in the form of raw shrimp, there are still many business opportunities and employment opportunities related to the shrimp business. For example, raw shrimp produced for each harvest can be processed into other products, such as shredded shrimp, shrimp crackers, shrimp paste, and shrimp nuggets. The processed production can be a business opportunity and job opportunity for residents of the Bumi Dipasena Village.

4.3.4 Upholding the principle of cooperation that is family and moral in Pancasila.

The principle of cooperation and sense of kinship that is moral in Pancasila can be seen from the implementation of profit sharing and the concept of the CRU (business risk reserve) that reflects cooperation, shared responsibility, and mutual cooperation. For example, the application of business risk reserves (CRU) is shared by farmers in each of UB (joint ventures). If one farmer in one UB experiences crop failure, other farmers will feel the same. The impact is that the farmers carry out joint monitoring of pond plots in mutual cooperation.

\section{Conclusion and Implication}

\subsection{Conclusion}

The concept of Business Risk Reserves (CRU) in the joint venture partnership pattern on Bumi Dipasena makes farmers feel more confident and think positively in terms of shrimp farm management. For example, if there is a problem with crop failure, cross-subsidies can be made for the finances of ponds in a business unit, and when surplus, farmers can contribute to the CRU. Easy is the CRU concept. In 3 good cycles of shrimp farming, farmers can save for the preparation of 1 bad cycle with the CRU concept.

The Infaq concept $(2.5 \%)$, which is intended to repair roads, bridges, schools, help places of worship and the construction of other facilities, also helps the lives of families of farmers who live in Dipasena.

In addition to the CRU concept, cooperatives or business units cooperate with farmers with funds of 1000 rupiah, i.e. in $1 \mathrm{~kg}$ of shrimp given 1000 rupiah to P3UW cash to buy heavy equipment (excavator). Excavators 
are used to improve facilities and infrastructure in the village. The farmers also felt helped by the concept of 1000 rupiah per kilogram. Then there is also what is called emergency debt. Farmers who experience financial difficulties will be assisted with emergency debt and will be returned at harvest and without interest.

Not all dimensions of people's economy such as empowerment and independence of the community in mastering economic resources, ranging from capital, assets and production processes and product marketing (From the People, By the People, To the People), government participation in determining public policies that support, develop entrepreneurship so that opening business opportunities and job opportunities and upholding the principles of cooperation that are family-based and moral in Pancasila, have been reflected in the implementation of the shrimp farming business in Dipasena Jaya Village.

Community empowerment and independence is important in mastering economic resources, starting from capital, assets and production processes and product marketing (From the people, by the people, to the people). This can be seen from many farmers who are also investors, and then most of the farm assets are already owned by the farmers. Then in the process of shrimp farming, farmers are the core actors of all cultivation activities. Starting from the input process to the process of selling shrimp yields, farmers have the right to choose suppliers and collectors. In essence, all aspects of the shrimp farming process are optimized for the good of farmers.

In terms of government participation, the role seen is the Village Government or in other words the village level. Actors involved in the Village Government are also actors who are actively involved in aquaculture activities on Bumi Dipasena. The function of the Village Government in this case is to oversee the cultivation activities and business of shrimp farms. In addition, the role or participation of the Government has not been seen. This can be seen from the condition of the infrastructure both roads and bridges that are not good and the inhabitants of Bumi Dipasena also strive to maintain and manage the existing infrastructure for the survival of the farmers.

The concept of entrepreneurship run by Bumi Dipasena village farmers currently focuses on shrimp farming entrepreneurship and other business opportunities from complementary shrimp farming products, ranging from seeds, saprotam, and fuel to windmills and also the opportunity to become shrimp collectors and distributors.

In its application, the shrimp farm business in Bumi Dipasena upholds the principles of family-friendly and moral in Pancasila cooperation. This can be seen from the implementation of profit sharing and the concept of the CRU (business risk reserve) that reflects cooperation, shared responsibility, and mutual cooperation. For example, the application of business risk reserves (CRU) is shared by farmers in each of UB (joint ventures). So if one farmer in one UB experiences crop failure, other farmers will feel. The impact is that the farmers carry out joint monitoring of pond plots in mutual cooperation.

\subsection{Implication}

1. In terms of government participation, it is better not only village government to play a role in pond business in Bumi Dipasena, but also district or even provincial governments. This is because Dipasena is actually a huge potential for shrimp ponds in Lampung and even Indonesia if supported by all parties. Examples include inadequate road and electricity access. The road infrastructure to the shrimp pond village is still very damaged and difficult to access. PLN electricity has not yet entered there. They still use solar and diesel electricity.

2. Apart from shrimp farming and the sale of harvest products in the form of raw shrimp, there are still many business opportunities and job opportunities related to the shrimp business. For example, raw shrimp produced for each harvest can be processed into other products, such as shredded shrimp, shrimp crackers, shrimp paste and shrimp nuggets. The processed production can be a business opportunity and job opportunity for residents of the Bumi Dipasena Village.

\section{References}

Anonymous (1995). Law Number 9 of 1995 concerning Small Businesses.

Anonymous (2016). Company Profile Earth Dipasena. Rawajitu. Tulang Bawang.

Corcoran, P.J, Walker, K.E, and Wals A.E.J, 2004. Case Studies, Make-Your-Case Studies and case stories: critique of case-study methodology in sustainability in higher education. Environmental Education Research. $10(1)$.

Dewi, F., Sari, L., \& Zainal, R. (2013). Consumer Behavior. Palembang: Citrabooks Indonesia.

Gibson, J.J. (1950). The Perception of the Visual World. Boston: Houghton Mifflin.

Kotler, P., \& Keller, K. L. (2012), Marketing Management, Global Edition 14e, London: Pearson Education Limited.

Malau, NA. (2016). Democratic Economy as a New Paradigm and Strategy in Indonesian Economic Development. VoL.2 No.1 Scientific Research Scientific Journal.

Notoatmodjo, S. (2003). Health Education and Behavior. Jakarta: Rineka Cipta.

Oyeyemi, M. (2015). The Effect of Perception of Extension Service on Small Farm Holders Agricultural Production. Journal of Economics and Sustainable Development. 6(12). PP 103-113. 
Putra, MUM. (2015). The Concept of Population Economic Development in Medan City. Mikroskil Economic Entrepreneur Journal. 5 (01).

Utama, HP. (2009). Analysis of Islamic Law Against the Pattern of Partnerships in the Business of Broiler Chicken Farms at PT Kenongo Perdana Pasuruan. Undergraduate thesis, UIN Sunan Ampel Surabaya.

Zulkarnain. (2006). Entrepreneurship Strategy for Small Business Empowerment Middle and Poor Population. Publisher of Adi Cipta Karya Nusa, Yogyakarta. 